\title{
The Role of Past Experience with a Single Climate Physical Risk in Adaptation Response to Multiple Climate Physical Risks: A Multiple Case Study of Italian Companies
}

\author{
Federica Gasbarro ${ }^{1}$, Tiberio Daddi $^{2} \&$ Fabio Iraldo $^{2}$ \\ ${ }^{1}$ Department of Economics and Management, University of Brescia, Brescia, Italy \\ ${ }^{2}$ Institute of Management, Sant'Anna School of Advanced Studies, Pisa, Italy \\ Correspondence: Federica Gasbarro, Department of Economics and Management, University of Brescia, Brescia, \\ Italy. E-mail: federica.gasbarro@unibs.it
}

\author{
Received: October 18, $2019 \quad$ Accepted: November 10, $2019 \quad$ Online Published: November 29, 2019 \\ doi:10.5539/jms.v9n2p162 URL: https://doi.org/10.5539/jms.v9n2p162
}

\begin{abstract}
With the increasing occurrence and intensity of weather and climate extremes, adaptation to climate change has become an imperative for all the societal actors, including companies. Business adaptation behavior is influenced by specific internal and external conditions. Based on a multiple case study of Italian companies within the project Life IRIS (Improve Resilience of Industry Sector), the paper examines the interaction of multiple physical risk drivers and organizational factors that trigger a change in the adaptation behavior of companies to climate change, from a deferred behavior to a reactive one and, then, to a pre-emptive behavior over time. In particular, the study shows how past experience with a single climate event can trigger a comprehensive strategy to deal with multiple climate events. Implications for management practice and policymakers are discussed at the end of the paper.
\end{abstract}

Keywords: corporate adaptation to climate change, business responses to climate change, climate risk management, corporate strategy, natural disasters, climate change

\section{Introduction}

As the detrimental role of human activity on the global climate has been acknowledged, political, social and business actors need to direct their efforts towards researching alternative patterns of production and consumption to mitigate climate change, in order to affect the rate and magnitude of change, while, at the same time, researching possible ways to adapt to climate change impacts on social and business activities (IPCC, 2014). While some uncertainty exists about the impacts of this change (e.g., the exact nature, timing, location, and magnitude), empirical scientific evidence clearly indicates the increasing likelihood and severity of extreme events and natural disasters, such as: droughts; flooding; hurricanes; extreme and unpredictable weather patterns (IPCC, 2012).

Therefore, the need of adaptation measures to reduce the vulnerability and increase the human and environmental resilience against the impacts of current and future climate change requires enhanced disaster risk reduction and preparedness (UN Global Compact \& UNEP, 2012). However, the capacity to mitigate and adapt is dependent on socio-economic and environmental circumstances and on the availability of information and technologies (IPCC, 2014). Besides, there are two more conditions restraining the definition and implementation of effective adaption programs: 1) there is a multiple impact problem (i.e., there are multiple potential climate events and related impacts); 2) there is the problem of responsibility and legitimacy when addressing a potential impact (Orlove, 2009).

In fact, historically, public organizations have been responsible for dealing with disasters, in particular the lowest jurisdictional level responsible in an impacted area (McKnight \& Linnenluecke, 2016; Nguyen, Imamura, \& Iuchi, 2017). However, some studies highlight the importance of the private sectors for improving community resilience (McKnight \& Linnenluecke, 2016; Nguyen et al., 2017). Firms could activate society to adopt anticipatory measures to deal with the physical impacts of climate change (Berkhout, 2012; Linnenluecke, Griffiths, \& Winn, 2013). They could be precious partner in post climate events relief and disaster recovering (Johnson, Connolly, \& Carter, 2011). In fact, on the one hand companies need to adapt to climate-induced 
physical changes, on the other, they are developing adaptation abilities and resources, which could be partaken of with other stakeholders to avoid or reduce the climate change impacts (e.g., a stricter regulation on water use, a decrease of the demand in areas affected by a climate events; Gasbarro \& Pinkse, 2016). According to UN Global Compact and UN Environment Programme (UN Global Compact \& UNEP, 2012) business adaptation to climate change plays a very important role in supporting sustainable development and green economy.

Despite the expected positive outcome of the adaptation measures in term of loss avoidance and reduced financial costs of rebuilding after natural business, adaptation has not been implemented widely (Berkhout, Hertin, \& Gann, 2006; Galbreath, 2012). In fact, adaptive behavior of companies seems to be influenced by specific internal and external conditions (Berkhout et al., 2006). Therefore, the issue seems to be very complex, due not only to its novelty but also to the number of variables influencing business adaptation, both related to the multiple weather and climate-related events (Winn et al., 2011), and to business characteristics, such as the size, the previous experience, the awareness, and the specific business impacts by sector (e.g., Linnenluecke \& Griffiths, 2010). In addition, business behavior in terms of business response to climate is not stable but can change over time, which could be attributed to a change of awareness and/or vulnerability perception (Gasbarro \& Pinkse, 2016).

However, as far as we know, the studies on business adaptation to climate change have neglected the role of interaction of multiple risk drivers and organizational factors in triggering the adaptation process, in particular that of multiple physical risk drivers and past experience with a specific climate-physical risk. Therefore, the objective of this study is to show how companies deal with multiple physical risks related to climate change over time and to show how the past experience with one single climate-related event influences a comprehensive adaptation response to multiple climate physical risks.

A multiple case study within the project Life IRIS (Improve Resilience of Industry Sector) (http://www.lifeiris.eu/) provides empirical evidences to illustrate under what conditions businesses change the deferred adaptation strategy in an anticipatory adaptation strategy to deal with climate events. The results allow identifying how past experience with a single climate event can trigger a comprehensive strategy to deal with multiple climate events.

\subsection{Literature Review}

Climate change can affect organizations directly and indirectly in the many aspects they have to deal with: from regulation compliance to competitiveness, from assets and resource availability to public relations, from innovation to financial aspects, and also threatening physical security. Business exposure to such risks and opportunities are considered the drivers of business responses to climate change (Kolk \& Pinkse, 2004). The main climate-related risks and opportunities mentioned by the scholars are:

- Regulatory risks can take the form of regulating emissions of products (e.g., car emissions) or processes (Hoffman, 2004; Kolk \& Pinkse, 2004).

- Physical risks can pose major challenges to business companies. In fact, these are related to the occurrence of the weather and climate-related events and their dimensions (e.g., time, magnitude, location, predictability, and so on, for all dimensions see Winn et al., 2011). The occurrence of extreme weather events can also reach a threshold where it become a real threat to organizational survival (Linnenluecke, Griffiths, \& Winn, 2012).

- Supply chain risks. This kind of risk is related to the vulnerability of the suppliers, which could lead to higher material and energy costs (Lash \& Wellington, 2007).

- Technological risks. A carbon constrained world needs new markets such as renewable energies, low carbon products, green building, new financial services and so on (Wittneben \& Kiyar, 2009).

- Market risks. Customer demand can change in the direction of climate friendly products and in response to changes in weather and resource availability (Packard \& Reinhardt, 2000; Schultz \& Williamson, 2005).

- Litigation risks. Directors and officers can become vulnerable to shareholder litigations, e.g., when refusing to change emissions patterns (Lash \& Wellington, 2007).

- Reputation risks. Industries or companies can be exposed to reputational risks if they continue to rely on products, processes or practices that negatively affect the climate (Lash \& Wellington, 2007; Wittneben \& Kiyar, 2009).

- Financial risks. These occur when financial institutions consider environmental and sustainability performance in their investment decisions (Busch \& Hoffmann, 2007; Wittneben \& Kiyar, 2009).

Among these risks, Gasbarro and colleagues (2017) showed that those prevailing in the companies' perception 
derive from a combination of impacts associated to 1) climate-related physical changes; 2) climate-related regulatory changes; and 3) climate-related market and reputation changes. However, climate change is exposing companies to multiple risks at the same time (e.g., there are multiple potential climate events and related impacts) and this is limiting the implementation of effective business responses (Orlove, 2009). As an example, considering a risk as the combination of likelihood of occurrence of an event and the associated consequences, multiple physical drivers (e.g., change in precipitation extremes and droughts, sea level rise, snow and ice, tropical cyclone) could imply reduction/disruption in production capacity or inability to do business and increased capital costs (Gasbarro et al., 2017).

The literature on business responses to climate change has been focused on mitigation or adaptation responses with a limited understanding of the multiple drivers' interaction, cause of the complexity of the phenomena emerging from previous studies. Consequently, only certain aspects have been investigated up to now.

In fact, only considering the business responses in terms of adaptation to physical risks, the issue seems to be already very complex, due not only to its novelty but also to the number of influencing variables to be considered, both related to the weather and climate-related events and their dimensions (i.e., contextual climate physical risk drivers), and related to business characteristics, such as the size, the previous experience, awareness, business impacts in terms of sector and company specific vulnerabilities (Linnenluecke \& Griffiths, 2010).

Other organizational variables influencing business adaptation to climate change are the ability to adapt and the dependency on the impacted business (Hoffmann, Sprengel, Ziegler, Kolb, \& Abegg, 2009), and the organizational capabilities (Busch, 2011). Bremer and Linnenluecke (2017) suggest that the environmental attitudes and climate change knowledge influence the importance perception of adaptation and that the perceived climate-related risk acts as a mediator in this relationship. Pinkse and Gasbarro (2019) developed a model to interpret the adaptation process as an attentional process where the creation of awareness is determined by firms' risk perception and perceived uncertainty of climate change, which are influenced by the knowledge of the local ecosystems, and the perception of vulnerability is determined by the perceived impact of and past experience with climate stimuli, which are influenced by the controllability of climate events.

Past experience with climate events seems to have a role both in informing the companies about their vulnerability and in triggering a change in adaptation behaviors. In fact, firms can learn about climate change through past experience, which is used to assess a specific type of extreme event (Berkhout et al., 2006). Past experience enables firms to rely on known categories to interpret climate changes (Pinkse \& Gasbarro, 2019). This, in turn, allows firms to assess with more details in terms of losses and financial implications their vulnerability to the specific climate events experienced (Pinkse \& Gasbarro, 2019). Then, some firms having a deferred adaptation profile, postponing adaptation measures, could realize their vulnerability after falling afoul of damages from an extreme weather event and after that adopting a reactive adaptation behaviour (Gasbarro \& Pinkse, 2016). This means that companies are often caught by surprise (Haigh \& Griffiths, 2012). In fact, climate change poses novel risks to firms outside the range of previous experience since several climate events are unique (Linnenluecke \& Griffiths, 2010) and climate change trigger multiple drivers and related impacts at the same time (e.g., multiple risks), such as drought, cold waves and eat waves, tropical cyclones, extreme floods (Linnenluecke et al., 2012; Orlove, 2009; Winn et al., 2011). Therefore, the question is whether the occurrence of one single climate-related physical event, and the consequent interpretation process within the company, can influence, and how, a comprehensive adaptation response to all climate-related physical events threating a company.

As discussed above, as far as we know, the literature dealing with corporate responses to climate change in terms of adaptation neglected the multiple risks' interaction in triggering adaptation behaviors, in particular, the influence of past experience with a specific climate-physical risk on the adaptation process to other expected climate-physical risks. Therefore, the objective of this study is to provide empirical evidence of companies dealing with multiple physical risks related to climate change over time and to show how the past experience with one single climate-related event influence a comprehensive adaptation response to multiple climate physical risks.

\section{Method}

In order to illustrate the adaption process over time and the interaction of multiple climate-physical risks' and past experience with a specific climate-physical risk, triggering a change in the business behavior from a deferred to an anticipatory behavior, we found appropriate to develop an exploratory case study on an exemplary context (Siggelkow, 2007; Yin, 2009).

The project LIFE IRIS (Improve Resilience of Industry Sector) seemed a suitable research context to address our 
research objectives. In fact, the project was developed over time (from Sept. 2015 to March 2019) and involved several business partners moving from a deferred adaptation behavior to a definition of a plan addressing climate-induced physical changes. This allowed a longitudinal study.

The project IRIS (September 2015-March 2019), co-funded by the European Commission (EC) through the LIFE program, aims to support SMEs in becoming more resilient to climate change, by mean of adaptation measures. Among the other partners, the three business partners who designed and took part to the project are: Consorzio Attività Produttive Aree e Servizi (CAP Modena); S.I.PRO. Agenzia Provinciale per lo Sviluppo (S.I.PRO. Ferrara) and Carlsberg Italia. The former two are the park managers of two productive areas in Emilia-Romagna (Italy), while the latter is the 3rd brewer in Italy. For each company, an adaptation plan was defined, based on the results of a climate risk assessment. The co-funding of the EC for these partners encompassed the climate risk assessment and the definition of the adaptation plans but not the adaptation measures included in the plans.

This purposive sampling (Pratt, 2009) allowed identifying companies making a change in their adaption behavior to the climate stimuli over time and the underlying meaningful variables driving this change.

Table 1. Overview of case characteristics

\begin{tabular}{|c|c|c|c|c|c|}
\hline Case & Kind of business & Company characteristics & Interviewees & Region & Business description \\
\hline $\begin{array}{l}\text { Consorzio Attività } \\
\text { Produttive Aree e } \\
\text { Servizi - CAP } \\
\text { Modena }\end{array}$ & $\begin{array}{l}\text { Industrial area } \\
\text { management }\end{array}$ & $\begin{array}{l}\text { Bomporto Industrial area } \\
\text { managed: } \\
95 \text { hectares } \\
72 \text { enterprises, with } \\
\text { manufacturing prevalence } \\
(60 \%) \\
1200 \text { employees } \\
\text { Management of three } \\
\text { productive areas classified as } \\
\text { Ecologically Equipped } \\
\text { Productive Areas }\end{array}$ & $\begin{array}{l}\text { Technical Office } \\
\text { Section Manager; } \\
\text { Climate consultants }\end{array}$ & $\begin{array}{l}\text { Modena } \\
\text { (Emilia } \\
\text { Romagna) }\end{array}$ & $\begin{array}{l}\text { Design and } \\
\text { Management of } \\
\text { Industrial Areas to } \\
\text { Develop Networks } \\
\text { and Supply } \\
\text { Infrastructure and } \\
\text { Quality Areas }\end{array}$ \\
\hline $\begin{array}{l}\text { S.I.PRO. Agenzia } \\
\text { Provinciale per lo } \\
\text { Sviluppo - S.I.PRO. } \\
\text { Ferrara }\end{array}$ & $\begin{array}{l}\text { Industrial area } \\
\text { management }\end{array}$ & $\begin{array}{l}\text { Ostellato Industrial area } \\
\text { managed: } \\
120 \text { hectares } \\
24 \text { enterprises, largely } \\
\text { belonging to manufacturing } \\
(70 \%) \\
650 \text { employees } \\
\text { Since } 2003 \text { it has been } \\
\text { dealing with } \\
\text { Eco-development, linked to } \\
\text { Eco-industrial parks }\end{array}$ & $\begin{array}{l}\text { Operational } \\
\text { manager; Climate } \\
\text { consultants }\end{array}$ & $\begin{array}{l}\text { Ferrara } \\
\text { (Emilia } \\
\text { Romagna) }\end{array}$ & $\begin{array}{l}\text { Design and } \\
\text { Management of } \\
\text { Industrial Areas }\end{array}$ \\
\hline Carlsberg Italia & $\begin{array}{l}\text { Food and } \\
\text { beverage }\end{array}$ & $\begin{array}{l}\text { Number of employees: } 266 \\
3^{\circ} \text { Italian market producer } \\
1^{\circ} \text { beer company in the world } \\
\text { with an } \\
\text { EPD certification } \\
\text { (Environmental Product } \\
\text { Declaration) }\end{array}$ & $\begin{array}{l}\text { CEO; Corporate } \\
\text { Affairs Manager; } \\
\text { HSE Manager; } \\
\text { Production Plant } \\
\text { Director; Suppliers } \\
\text { and packaging } \\
\text { manager; Quality } \\
\text { Manager; Sales } \\
\text { manager; Key } \\
\text { account manager; } \\
\text { Brewer master; } \\
\text { Carlsberg Supply } \\
\text { Company AG }\end{array}$ & $\begin{array}{l}\text { Production } \\
\text { plant: } \\
\text { Lombardy } \\
\text { Sales: Italy }\end{array}$ & $\begin{array}{l}\text { Beer production and } \\
\text { distribution } \\
\text { Around } 1,3 \text { mil. HL } \\
\text { beer/year } \\
34 \text { beers in the } \\
\text { portfolio }\end{array}$ \\
\hline
\end{tabular}

We conducted our case studies between March 2016 and December 2018. For the analysis we carried out semi-structured phone calls and face-to-face interviews with several managers during the project meetings (we attended six meetings), and we analyzed all the documents developed during the project (e.g., three climate risk assessments and three climate adaptation plans of the case studies), together with the companies' websites and press releases. We structured the interviews on the basis of three categories: climate drivers and related impact, and the adaptation measures to deal with these risks. However, not all the questions were necessarily used in each interview depending on the availability of complementary data sources. A content analysis of the gathered 
data gave rise to a storyline. The interpretation of cross-cases and theoretical patterns helped to shed light on the relationship between past experience with a specific climate-physical risk and the adaptation process to other expected climate-physical risks (Eisenhardt, 1989). Once we collected the information, we contacted the interviewees again by phone to clarify any issue that arose. Table 1 shows the participants characteristics and the interviewees in the study.

\section{Results}

\subsection{Carlsberg Italia}

Before taking part in the Life IRIS project, the Carlsberg's production plant was affected by floods three times, the last being in July 2009. The flood of 2009 caused damages to the plant not totally recognized by the insurance and entailing high economic losses. Although the previous floods did not lead the company to implement anticipatory adaptation measures with impacts on ecosystem services conservation, the last flood has evidently changed the perception of the company, which has decided to undertake a path of adaptation to climate change with non-routine measures. The business damages identified were in terms of asset integrity, business continuity, infrastructures, financial balance, staff health and safety and legal responsibility. Then in March 2010 a partnership started between the Region of Lombardy, the Po River Basin Authority, the Inter-regional Agency for the River Po, Induno Olona and Varese Municipalities and Carlsberg Italia, in order to search for solutions to the final hydraulic arrangement of the river Olona in the upstream part of the Carlsberg property. Carlsberg Italia at its own cost, carried out a study for the retention of the river Olona. In the same year, Carlsberg Italia started analyzing all its packages through the LCA (Product Life Cycle Analysis), obtaining the EPD certification-Environmental Product Declaration - for its main products in 2011. In 2014, Carlsberg Italia decided to take part in the design and then in the realization of the IRIS project, committing to assess the physical risks from climate change centered not only on the driver of extreme precipitations and consequent floods, but also on other physical drivers, and, based on this assessment, to define an adaptation plan.

The climate risk assessment highlighted several business risks for Carlsberg Italia, which represented a trigger for identifying and implementing some climate adaptation measures with positive impacts on the community. As emerged in the climate risk analysis the main physical risks posed by climate change to Carlsberg Italia concern the procurement of raw materials, the production plant, the sales and logistics.

In particular, the supplies of barley and hops (Zeus variety) seem both threatened by intense rainfalls, extreme hot temperatures and drought. This negative trends in the barley and hops production could threaten the business continuity and the financial balance of Carlsberg Italia. According to Carlsberg Supply Company, barley production is not very much influenced by the climate, but rather resilient, and the company has already in place some commercial mechanisms to control the raising prices of the raw materials.

Considering the Induno Olona production plant, the availability of water could be affected by the rising temperatures. The manufacturing plant is threatened by the increase of rain intensity causing the flooding of the river Induno Olona. The change in seasonality, intense thunderstorms during the main sales period (April-September) and the heat waves impact the sales and the logistics, as well as the workers.

Then, five adaptation measures have been identified and implemented. The first was a study to investigate the possible impacts of climate change on water supply sources and to identify any adaptation measure to improve the company's resilience. As resulted in the climate change risk assessment the water provisioning of the production plan is at risk cause of the climate change. Since the water availability is related to the raining, a rain reduction could affect the quantity of the available water and trigger possible conflict with the local community including civil society and neighbor companies relying on the same water sources. In addition, in recent years in presence of extreme raining and droughts the depuration filter was obstructed, then needed an unplanned cleaning and production delays. This measure was based on an ecosystem-based approach on the ecosystem service of water provisioning. The second was a study on health conditions of the plants within the factory park with the identification of subsequent maintenance needs. The production plant property is part of the Parco Regionale Campo dei Fiori and is covered with large wooded areas. Carlsberg Italia noticed that several trees were sick. Recognizing the value of the wooded area in the provision of ecosystem service of soil regulation, erosion and landslide prevention and the safeguarding of the hydrogeological system, Carlsberg Italia considered necessary to deepen the nature of the phenomenon and possibly to act. In fact, as the ecosystem service of soil regulation is no longer available, the Induno Olona flooding risk could increase as well as the risk of landslides. Further six measures have been identified following the results of the study on water resources and on the protection of plants belonging to the Regional Park of Campo dei Fiori.

The potential impacts identified by this company as more relevant are: the threat of regulation for clean water 
resources; the reputational risks; the business continuity; the market response; and the financial balance. Many identified adaptation measures therefore aim to preserve the functions of ecosystem services and thus ensure the business continuity. Other actions aim to reduce the health risks for workers in conjunction with the heat waves due to climate change.

The choice of the actions was due to a feasibility assessment of the measures (identification, implementation and monitoring) within the timing of the IRIS project and the priorities set by Carlsberg Group, to which Carlsberg Italia refers. These priorities are 1) Water; 2) Energy and Climate; 3) Staff, Health \& Safety. However, the climate risk assessment gave rise to a new awareness among the employees. The adaptation measures identified by Carlsberg Italia are listed in Table 2.

Table 2. Adaptation measures of Carlsberg Italia

\begin{tabular}{|c|c|c|c|}
\hline Adaptation measures & $\begin{array}{l}\text { Expected risk } \\
\text { driver }\end{array}$ & $\begin{array}{l}\text { Expected } \\
\text { business } \\
\text { impact }\end{array}$ & Timeline \\
\hline $\begin{array}{l}\text { Action } 1 \text {-Feasibility study for the replacement of the pasteurizer, aimed to reduce } \\
\text { the health risks for workers in conjunction with heat waves due to climate change. }\end{array}$ & Heat waves & $\begin{array}{l}\text { Staff Health and } \\
\text { Safety }\end{array}$ & March 2017 \\
\hline $\begin{array}{l}\text { Action } 2 \text {-Open Air Job: Installation of desks in the factory park, aimed to reduce the } \\
\text { health risks for workers related to the increasing trend of the temperature. }\end{array}$ & Heat waves & $\begin{array}{l}\text { Staff Health and } \\
\text { Safety }\end{array}$ & May 2018 \\
\hline $\begin{array}{l}\text { Action } 3 \text { - Hydrogeological study, aimed to investigate the possible impacts of } \\
\text { climate change on water supply sources and identify possible adaptation measures to } \\
\text { improve the company's resilience. }\end{array}$ & Drought; Floods & $\begin{array}{l}\text { Assets Integrity; } \\
\text { Business } \\
\text { Continuity }\end{array}$ & April 2017 \\
\hline $\begin{array}{l}\text { Action } 4-\text { Study on the protection of the wood belonging to the factory's park, in } \\
\text { order to safeguard its provision of ecosystem service of soil regulation, erosion and } \\
\text { landslide prevention and the safeguarding of the hydrogeological system. }\end{array}$ & $\begin{array}{l}\text { Extreme } \\
\text { precipitations }\end{array}$ & Assets Integrity & December 2017 \\
\hline $\begin{array}{l}\text { Action 5-Pasteurizer replacement, following the feasibility study (Action 1) it was } \\
\text { decided to invest in a flash pasteurization. }\end{array}$ & Heat waves & $\begin{array}{l}\text { Staff Health and } \\
\text { Safety }\end{array}$ & May 2018 \\
\hline $\begin{array}{l}\text { Action } 6 \text { - Implementation of a continuous monitoring system of the flow, } \\
\text { temperature and electrical conductivity of water resources for the definition of source } \\
\text { depletion curves. }\end{array}$ & Heat waves & $\begin{array}{l}\text { Business } \\
\text { Continuity }\end{array}$ & June 2019 \\
\hline $\begin{array}{l}\text { Action 7-Evaluation of the technical possibility of water provisioning from local } \\
\text { water public utility in order to deal with possible water shortages in conjunction with } \\
\text { drought events. }\end{array}$ & Heat waves & $\begin{array}{l}\text { Business } \\
\text { Continuity }\end{array}$ & December 2018 \\
\hline $\begin{array}{l}\text { Action } 8 \text { - Removal of all disused pipes located within the covered section of the } \\
\text { Olona River, in order to increase the hydraulic section useful for water runoff in case } \\
\text { of extreme rainfall. }\end{array}$ & Flood & $\begin{array}{l}\text { Assets Integrity; } \\
\text { Business } \\
\text { Continuity }\end{array}$ & March 2018 \\
\hline $\begin{array}{l}\text { Action 9-Positioning of a water gauge in order to identify the water level of alert in } \\
\text { case of extreme precipitations. }\end{array}$ & Flood & $\begin{array}{l}\text { Assets Integrity; } \\
\text { Business } \\
\text { Continuity }\end{array}$ & March 2018 \\
\hline $\begin{array}{l}\text { Action } 10-\text { Creation of a bridle for the detention of debris upstream in the riverbed in } \\
\text { order to protect the hydraulic section useful for water runoff, especially in the event of } \\
\text { extreme rainfall. }\end{array}$ & Flood & $\begin{array}{l}\text { Assets Integrity; } \\
\text { Business } \\
\text { Continuity }\end{array}$ & March 2018 \\
\hline $\begin{array}{l}\text { Action } 11-\text { Suppliers involvement in training and drilling to deal with extreme } \\
\text { events in the factory and to guarantee the business continuity. }\end{array}$ & Flood & $\begin{array}{l}\text { Business } \\
\text { Continuity }\end{array}$ & December 2018 \\
\hline
\end{tabular}

\subsection{CAP}

CAP was affected by a tornado in 2013 and a flood in 2014, causing various damages to the enterprises located in the cluster and entailing huge restoration costs. In fact, the damages recorded by the companies in Bomporto, due to the flooding in 2014, amounted to $10,657,590$ euros, divided into 2,893,288 euros for restoring the structures, 3,480,159 euros for the machinery restoration, and 4,284,143 euros for the damaged goods. In addition, the costs for restoring the gas and sewage networks and the water purification plant amounted to approximately 600,000 euros. This changed the perception of the park manager on climate change and triggered the need to define some adaptation measures with the aim of improving resilience. The climate risk assessment of Bomporto cluster managed by CAP highlighted that extreme precipitations (driving river flooding) and tornadoes, together with heatwaves, are the riskiest climate events. With the occurrence of these climate events, the cluster encounters serious economic consequences because of decrease in productivity of the companies settled here, and because of the large costs for restoring the functionality of technology networks or basic services, and of recovering of damaged infrastructure and public spaces. Furthermore, the companies may have to bear extra expenses not budgeted or to request loans to third parties for the repair of the structures, but also for any redemption payments to third parties in case of environmental crimes or violations of law due to weather 
extremes. From a social point of view, the most serious consequences would cover any deterioration of the health and safety of workers, especially in case of the damages to factories and to public areas, resulting in a loss credibility and reputation for the entire industrial area. The environmental consequences could be due to infrastructural problems (logistical difficulties to enter in the industrial area and/or limiting the mobility of employees) due to damage to the green and to the trees, which in severe cases may also cause contamination or pollution. To summarize the business risks identified are: asset integrity, business continuity, financial balance, legal liability, infrastructures, staff health and safety and reputation. CAP Adaptation Plan reflects the results of the risk analysis and identifies 13 actions that can be subdivided in three main categories: information activities and technical services directed to the companies, and urban regeneration of the industrial area. The plan was discussed and reviewed with the participation of all the companies of the industrial park and all the beneficiaries of the project. The actions identified in the adaptation plan included both mitigation and adaptation measures of climate change. Cause of the considerable economic investments, the interventions are planned in ten years, therefore they do not constitute an immediate and decisive response to the consequences of climate change, but they provide advantages extended to the whole community over the long term.

The actions concern both the public and private spaces in the industrial area. From a temporal point of view the actions have been designed to be carried out over a period of 10 years and to be implemented in two steps: the first six to be implemented by the end of 2018 and the following ones, to be programmed in a longer period depending on the economic and financial resources availability. This would allow a first phase of training and informational measures, aimed at involving the companies in the cluster in the adaptation process and preparing the ground for subsequent actions. Following the analysis of physical risk due to climate change, the measures aimed at adapting to intense precipitations, tornados and heat waves were considered a priority. In addition, the players started a dialogue with the local public institutions in order to accelerate the adaptation measures under their responsibilities. First actions are intended to create a virtuous process in which the stakeholders can create the collaborations necessary to trigger public-private partnership mechanisms in order to promote interventions for the resilience of the area. The adaptation measures identified by CAP are listed in Table 3.

Table 3. Adaptation measures of CAP

\begin{tabular}{|c|c|c|}
\hline Adaptation measures & Expected risk driver & Timeline \\
\hline $\begin{array}{l}\text { Action 1-Info Point for companies: creation of a reference office within the Modena } \\
\text { Productive Activities Consortium to coordinate all climate change mitigation and } \\
\text { adaptation activities and energy efficiency. }\end{array}$ & $\begin{array}{l}\text { Cold waves; heat waves; } \\
\text { tornados; extreme precipitations }\end{array}$ & From 2017 to 2026 \\
\hline $\begin{array}{l}\text { Action 2-Training for companies: organization of seminars and educational } \\
\text { workshops to raise awareness among local operators on resilience and promote concrete } \\
\text { actions to adapt to climate change. }\end{array}$ & $\begin{array}{l}\text { Cold waves; heat waves; } \\
\text { tornados; extreme precipitations }\end{array}$ & From 2017 to 2026 \\
\hline $\begin{array}{l}\text { Action 3-Business Climate Desk: assessment of corporate vulnerability to weather and } \\
\text { climate events. }\end{array}$ & $\begin{array}{l}\text { Cold waves; heat waves; } \\
\text { tornados; extreme precipitations }\end{array}$ & From 2017 to 2020 \\
\hline Action 4-Emergency plan and automatic alert. & $\begin{array}{l}\text { waves; } \\
\text { precipitations }\end{array}$ & From 2017 to 2018 \\
\hline $\begin{array}{l}\text { Action 5-Simulation of ex-ante and ex-post outdoor comfort: elaboration of maps of } \\
\text { the thermal comfort of the industrial sector to the current state and simulation of the } \\
\text { effects produced by the actions on the public spaces envisaged by the Adaptation Plan. }\end{array}$ & $\begin{array}{l}\text { Heat waves; tornados; extreme } \\
\text { precipitations }\end{array}$ & From 2017 to 2018 \\
\hline $\begin{array}{l}\text { Action } 6 \text { - Urban forestry: planting of new tree species to increase the level of thermal } \\
\text { comfort of the cluster. }\end{array}$ & $\begin{array}{l}\text { Cold waves; heat waves; } \\
\text { tornados; extreme precipitations }\end{array}$ & From 2018 to 2019 \\
\hline $\begin{array}{l}\text { Action 7-Pocket garden: transformation into green of an unused interstitial space in } \\
\text { order to reduce its degradation and increase its use and attractiveness. }\end{array}$ & $\begin{array}{l}\text { es; tornados; Extreme } \\
\text { ions }\end{array}$ & From 2019 to 2020 \\
\hline $\begin{array}{l}\text { Action } 8 \text {-Draining paving: de-waterproofing and de-paver } \\
\text { percentage of permeable soils and counteract heat waves. }\end{array}$ & $\begin{array}{l}\text { Heat waves; tornados; Extreme } \\
\text { precipitations }\end{array}$ & From 2020 to 2021 \\
\hline $\begin{array}{l}\text { Action 9-Rain gardens: creation of depressed roadside flower beds capable of } \\
\text { intercepting rainwater from roofs, roads and parking lots. }\end{array}$ & $\begin{array}{l}\text { Heat waves; tornados; Extreme } \\
\text { precipitations }\end{array}$ & From 2021 to 2023 \\
\hline $\begin{array}{l}\text { Action } 10 \text { - Flood basin: construction of a basin for storage, purification and/or } \\
\text { infiltration of rainwater. }\end{array}$ & Extreme precipitations & From 2022 to 2025 \\
\hline $\begin{array}{l}\text { Action 11-“Cold" materials: incentives for private companies to replace the roof } \\
\text { covering of existing sheds with a high SRI (Solar Reflectance Index) coating and/or } \\
\text { painting the facades of buildings with reflective anti-radiation paints. }\end{array}$ & Heat waves & From 2021 to 2026 \\
\hline $\begin{array}{l}\text { Action } 12 \text { - Implementation of municipal planning instruments: integration of the } \\
\text { existing urban planning instruments applied to the industrial sector, with objectives and } \\
\text { provisions for environmental and microclimatic improvement and maintenance of } \\
\text { biodiversity. }\end{array}$ & $\begin{array}{l}\text { Cold waves; heat waves; } \\
\text { tornados; extreme precipitations }\end{array}$ & From 2022 to 2026 \\
\hline \multicolumn{2}{|l|}{ Action 13-LED lighting: replacement of the lighting bodies with LED technology bodies } & From 2025 to 2026 \\
\hline
\end{tabular}




\subsection{S.I.PRO.}

Differently by the previous two companies, the cluster S.I.PRO. did not experience flooding or tornadoes before taking part in the project IRIS, only heatwaves without material costs. However, it was concerned about the effects of climate change after witnessing the climate extremes affecting other industrial areas in the region and being urged to act by a stakeholder concerned by climate extremes happening in the surroundings. In the climate risk assessment, S.I.PRO. identified the highest risky climatic events in heatwaves and tornados. The former is related particularly to impacts on asset integrity, business continuity, staff health and safety while the latter could have potential impacts on the whole business activity and, in particular, on business continuity, and on the infrastructures. In terms of vulnerability, S.I.PRO. assessed its highest vulnerability in relation to market response and reputation impacts related to heatwaves and drought. The main objective of the adaptation plan was to analyze the context of the industrial area of Ostellato and to identify some preventive actions and operational solutions to increase the resilience of the companies in the area to extreme climate events. Therefore, it has identified 10 adaptation actions for the industrial area of Ostellato: information activities and technical services directed to the companies, and stakeholder engagement and communication measures. This plan has a strong emphasis on the direct involvement of individual companies in the industrial cluster and on the support of the local public administration. The adaptation measures identified by S.I.PRO. are listed in Table 4.

Table 4. Adaptation measures of S.I.PRO.

\begin{tabular}{|c|c|c|}
\hline Adaptation measures & Expected risk driver & Timeline \\
\hline $\begin{array}{l}\text { Action 1-Adaption Helpdesk to inform companies on adaptation issues, provide technical } \\
\text { and financial assistance for the implementation of adaptation actions. }\end{array}$ & $\begin{array}{l}\text { Cold waves; heat } \\
\text { waves; tornados; } \\
\text { extreme precipitations }\end{array}$ & From 2017 to 2018 \\
\hline $\begin{array}{l}\text { Action 2-Training for companies: Organization of training seminars and educational } \\
\text { workshops for companies in order to raise awareness among local operators on resilience. }\end{array}$ & $\begin{array}{l}\text { Cold waves; heat } \\
\text { waves; tornados; } \\
\text { extreme precipitations }\end{array}$ & From 2017 to 2018 \\
\hline $\begin{array}{l}\text { Action 3-Industrial Adaptation Assessment: Creation of a consultancy service for the } \\
\text { assessment of corporate vulnerability to weather and climate events. The service includes an } \\
\text { on-site inspection, a vulnerability assessment and a proposal for mitigation and adaptation } \\
\text { interventions, with priority reporting. }\end{array}$ & $\begin{array}{l}\text { Cold waves; heat } \\
\text { waves; tornados; } \\
\text { extreme precipitations }\end{array}$ & 2017 \\
\hline $\begin{array}{l}\text { Action } 4 \text {-Support in the elaboration of a Business Adaptation Plan: it foresees a support in the } \\
\text { realization of a Company Adaptation Plan that favors a reduction of the risks and consequently } \\
\text { of the costs linked to the occurrence of extreme climatic events. }\end{array}$ & $\begin{array}{l}\text { Cold waves; heat } \\
\text { waves; tornados; } \\
\text { extreme precipitations }\end{array}$ & From 2017 to 2018 \\
\hline $\begin{array}{l}\text { Action 5-Adaptation and mitigation of the risk of heat waves. Organization of a working } \\
\text { table with institutions and stakeholders for the definition of a program of management of } \\
\text { existing green areas and the requalification with new plantings of about } 50,000 \text { square meters, } \\
\text { in order to mitigate the effects of heat waves. }\end{array}$ & Heat waves & From 2017 to 2019 \\
\hline $\begin{array}{l}\text { Action 6-Adaptation and mitigation of the risk of river flooding. Prevention by cleaning the } \\
\text { drainage ditches and adopting interventions aimed at isolating the area in the event of flooding } \\
\text { of the surrounding rivers by permanent and mobile protections, such as perimeter walls, gates, } \\
\text { underpasses and drains. }\end{array}$ & Flood & From 2017 to 2026 \\
\hline $\begin{array}{l}\text { Action 7-Safeguarding endemic and settlement ecosystems. Selection and planting of new } \\
\text { trees to improve adaptability in the S.I.PRO green area. }\end{array}$ & Heat waves & From 2019 to 2021 \\
\hline $\begin{array}{l}\text { Action 8-Adaptation and mitigation of the drought risk. The action includes training on } \\
\text { reducing water consumption and reducing losses in distribution networks, and it includes also } \\
\text { the development of rainwater collection and treatment systems. }\end{array}$ & Drought & From 2020 to 2022 \\
\hline $\begin{array}{l}\text { Action } 9 \text {-Adaptation and mitigation of the risk of air horns. Lowering the local temperature } \\
\text { by planting green areas. }\end{array}$ & Tornados & From 2021 to 2023 \\
\hline $\begin{array}{l}\text { Action 10-Adaptation and mitigation of the risk of overheating. The action aims to promote } \\
\text { the adoption of cold materials in order to avoid the negative effects of overheating of buildings } \\
\text { such as thermal discomfort and related health problems, energy consumption for the } \\
\text { conditioning and durability of the most exposed building elements. }\end{array}$ & Heat waves & From 2017 to 2026 \\
\hline
\end{tabular}

\section{Discussion and Conclusion}

The paper provided empirical evidences of companies dealing with multiple physical risks related to climate change over time and showed how the experience with one single climate-related event influences a comprehensive adaptation response to multiple climate physical risks. The results shed light on the mechanisms driving the change in the adaptation behavior of companies to climate change, from a deferred behavior to a 
reactive one and, then, to a pre-emptive behavior over time. In particular, the past experience with a specific climate-related event triggered on the one hand a reactive adaptation behavior towards that specific event, and, on the other, a pre-emptive adaptation behavior towards multiple other potential climate-related weather events. Indeed, the lack of adaptation measures, leaving the companies vulnerable, and the occurrence of extreme weather-related events, which caused significant damage to companies (in the case of Carlsberg Italia and CAP) or to nearby companies (in the case of S.I.PRO.), represented a turning point in the interpretation of climate risks and related vulnerability (Pinkse \& Gasbarro, 2019). This change triggered not only the need to reduce the risk associated with the specific experiences (e.g., flooding and tornadoes), as suggested by the previous literature (Berkhout et al., 2006; Linnenluecke \& Griffiths, 2010; Pinkse \& Gasbarro, 2019), but also to assess and then reduce the risks associated with other expected meteorological and climatic events, even though not yet occurred. In practice, a strategy to postpone adaptation has left the businesses vulnerable to climatic events, with consequences in terms of losses and reconstruction costs after the occurrence of the natural disasters. Then the experience with previous climatic events has activated the risk management for this type of events but has also changed the way of dealing with other potential climate-related extremes. However, the willingness to take part in the IRIS project, implying a comprehensive assessment of the climate-related physical risks (i.e., different climate-related events and the related direct and indirect impacts) and then the definition of a climate adaptation plan, seemed to be also driven by the particular attention paid to the environmental problems and in particular to the mitigation of climate change as suggested by Bremer and Linnenluecke (2017). In fact, all the companies investigated were involved in reducing their environmental footprint before starting the climate adaptation process (e.g., EPD certification for Carlsberg Italia and Ecologically Equipped Productive Areas for CAP and S.I.PRO.). This could be interpreted as a greater awareness of climate change, which together with the perception of greater vulnerability due to losses related to experience with previous climatic events, triggered a change of behavior from a deferred to a reactive one towards the climate-related events experienced and, then, to a pre-emptive behavior towards other potential climate-related events. This led to the implementation of several non-routine adaptation measures.

The paper provides a contribution to the literature on corporate responses to climate change by confirming and extending the previous studies. In fact, on the one hand, the previous studies highlighted the role of past experience with a specific event (i.e., climate-related physical risk) in the adaptation response to that type of event (Berkhout et al., 2006; Linnenluecke \& Griffiths, 2010; Pinkse \& Gasbarro, 2019), however we showed that this has a role also in triggering the adaption process in response to other climate-related physical risks.

On the other, if adaption behaviors can be reactive or anticipatory (Fankhauser, Smith, \& Tol, 1999; Gasbarro \& Pinkse, 2016; Haigh \& Griffiths, 2012; Smit, Burton, Klein, \& Wandel, 2000), or both in different installations depending on location-specific weather and climate events (Gasbarro \& Pinkse, 2016), our results allow to confirm and complement these research by showing that companies can have different types of adaptation behaviors simultaneously not only across facilities but also within the same facility in order to deal with multiple climate physical risks.

The results of this study could inspire business and local decision makers having a deferred adaption behavior towards climate change. In fact, in a world with an increasing trend in terms of intensity and frequency of weather and climate extremes (IPCC, 2012), postponing adaptation measures leave the organizations vulnerable. Therefore, the organizations with a wait and see approach, could reconsider their strategy learning from the experience of the case studies presented in this study and consequently carrying out a climate risk assessment to the expected multiple climate risks and then defining a climate adaptation plan in order to lower their vulnerability.

However, the paper is not without limitations. The purposive sampling does not allow generalizing the results. This calls for a wider and diversified selection of companies in further case studies. Furthermore, the study investigated only how the past experience with one single climate-related risk influences a comprehensive adaptation response to multiple physical risks over a limited time span (i.e., three years), however the adaptation plans could be modified over time (Gasbarro \& Pinkse, 2016). Therefore, further studies could investigate on the one hand the multiple climate risks' interaction in triggering business response to climate change both in terms of mitigation and in terms of adaptation over a longer time span, on the other, the influence of other organizational variables on business response to multiple climate risks.

\section{References}

Berkhout, F. (2012). Adaptation to climate change by organizations. Wiley Interdisciplinary Reviews-Climate Change, 3(1), 91-106. https://doi.org/10.1002/wcc.154 
Berkhout, F., Hertin, J., \& Gann, D. M. (2006). Learning to adapt: Organisational adaptation to climate change impacts. Climatic Change, 78(1), 135-156. https://doi.org/10.1007/s10584-006-9089-3

Bremer, J., \& Linnenluecke, M. K. (2017). Determinants of the perceived importance of organisational adaptation to climate change in the Australian energy industry. Australian Journal of Management, 42(3), 502-521. https://doi.org/10.1177/0312896216672273

Busch, T. (2011). Organizational adaptation to disruptions in the natural environment: The case of climate change. Scandinavian Journal of Management, 27(4), 389-404. https://doi.org/10.1016/j.scaman.2010.12.010

Busch, T., \& Hoffmann, V. H. (2007). Emerging carbon constraints for corporate risk management. Ecological Economics, 62(3-4), 518-528. https://doi.org/10.1016/j.ecolecon.2006.05.022

Eisenhardt, K. M. (1989). Building Theories from Case Study Research. Academy of Management Review, 14(4), 532-550. https://doi.org/10.5465/AMR.1989.4308385

Fankhauser, S., Smith, J. B., \& Tol, R. S. J. (1999). Weathering climate change: Some simple rules to guide adaptation decisions. Ecological Economics, 30(1), 67-78. https://doi.org/10.1016/S0921-8009(98)00117-7

Galbreath, J. (2012). Climate Change Response: Evidence from the Margaret River Wine Region of Australia. Business Strategy and the Environment, 23(2), 89-104. https://doi.org/10.1002/bse.1762

Gasbarro, F., Iraldo, F., \& Daddi, T. (2017). The drivers of multinational enterprises' climate change strategies: A quantitative study on climate-related risks and opportunities. Journal of Cleaner Production. https://doi.org/10.1016/j.jclepro.2017.03.018

Gasbarro, F., \& Pinkse, J. (2016). Corporate Adaptation Behaviour to Deal with Climate Change: The Influence of Firm-Specific Interpretations of Physical Climate Impacts. Corporate Social Responsibility and Environmental Management, 23(3), 179-192. https://doi.org/10.1002/csr.1374

Haigh, N., \& Griffiths, A. (2012). Surprise as a Catalyst for Including Climatic Change in the Strategic Environment. Business \& Society, 51(1), 89-120. https://doi.org/10.1177/0007650311427425

Hoffman, A. (2004). Winning the Greenhouse Gas Game. Harvard Business Review, 82(4), 20-21.

Hoffmann, V. H., Sprengel, D. C., Ziegler, A., Kolb, M., \& Abegg, B. (2009). Determinants of corporate adaptation to climate change in winter tourism: An econometric analysis. Global Environmental Change-Human and Policy Dimensions, 19(2), 256-264. https://doi.org/10.1016/j.gloenvcha.2008.12.002

IPCC. (2012). Managing the Risks of Extreme Events and Disasters to Advance Climate Change Adaptation. Cambridge, UK and New York, USA: Cambridge University Press.

IPCC. (2014). Summary for policymakers. In C. B. Field, V. R. Barros, D. J. Dokken, K. J. Mach, M. D. Mastrandrea, T. E. Bilir, M. Chatterjee, K. L. Ebi, Y. O. Estrada, R. C. Genova, B. Girma, E. S. Kissel, A. N. Levy, S. MacCracken, P. R. Mastrandrea \& L. L. White (Eds.), Climate Change 2014: Impacts, Adaptation, and Vulnerability (Part A: Global and Sectoral Aspects. Contribution of Working Group II to the Fifth Assessment Report of the Intergovernmental Panel on Climate Change). Cambridge, United Kingdom and New York, NY, USA: Cambridge University Press.

Johnson, B. R., Connolly, E., \& Carter, T. S. (2011). Corporate social responsibility: The role of Fortune 100 companies in domestic and international natural disasters. Corporate Social Responsibility and Environmental Management, 18(6), 352-369. https://doi.org/10.1002/csr.253

Kolk, A., \& Pinkse, J. (2004). Market Strategies for Climate Change. European Management Journal, 22(3), 304-314. https://doi.org/10.1016/j.emj.2004.04.011

Lash, J., \& Wellington, F. (2007). Competitive advantage on a warming planet. Harvard Business Review, 85(3), 94.

Linnenluecke, M., \& Griffiths, A. (2010). Beyond Adaptation: Resilience for Business in Light of Climate Change and Weather Extremes. Business \& Society, 49(3), 477-511. https://doi.org/10.1177/0007650310368814

Linnenluecke, M. K., Griffiths, A., \& Winn, M. (2012). Extreme Weather Events and the Critical Importance of Anticipatory Adaptation and Organizational Resilience in Responding to Impacts. Business Strategy and the Environment, 2l(1), 17-32. https://doi.org/10.1002/bse.708

Linnenluecke, M. K., Griffiths, A., \& Winn, M. I. (2013). Firm and industry adaptation to climate change: A 
review of climate adaptation studies in the business and management field. Wiley Interdisciplinary Reviews: Climate Change, 4(5), 397-416. https://doi.org/10.1002/wcc.214

McKnight, B., \& Linnenluecke, M. K. (2016). How Firm Responses to Natural Disasters Strengthen Community Resilience: A Stakeholder-Based Perspective. Organization \& Environment, 29(3), 290-307. https://doi.org/10.1177/1086026616629794

Nguyen, D. N., Imamura, F., \& Iuchi, K. (2017). Public-private collaboration for disaster risk management: A case study of hotels in Matsushima, Japan. Tourism Management, 61, 129-140. https://doi.org/10.1016/j.tourman.2017.02.003

Orlove, B. (2009). Glacier Retreat: Reviewing the Limits of Human Adaptation to Climate Change. Environment: Science and Policy for Sustainable Development, 51(3), 22-34. https://doi.org/10.3200/ENVT.51.3.22-34

Packard, K., \& Reinhardt, F. (2000). What every executive needs to know about global warming. Harvard Business Review, 78(4), 128+.

Pinkse, J., \& Gasbarro, F. (2019). Managing Physical Impacts of Climate Change: An Attentional Perspective on Corporate Adaptation. Business \& Society, 58(2), 333-368. https://doi.org/10.1177/0007650316648688

Pratt, M. G. (2009). From the Editors: For the Lack of a Boilerplate: Tips on Writing Up (and Reviewing) Qualitative Research. Academy of Management Journal, 52(5), 856-862. https://doi.org/10.5465/AMJ.2009.44632557

Schultz, K., \& Williamson, P. (2005). Gaining Competitive Advantage in a Carbon-constrained World: European Management Journal, 23(4), 383-391. https://doi.org/10.1016/j.emj.2005.06.010

Siggelkow N., N. (2007). Persuasion with Case Studies. Academy of Management Journal, 50(1), 20-24. https://doi.org/10.5465/amj.2007.24160882

Smit, B., Burton, I., Klein, R. J. T., \& Wandel, J. (2000). An anatomy of adaptation to climate change and variability. Climatic Change, 45(1), 223-251. https://doi.org/10.1023/A:1005661622966

UN Global Compact, \& UNEP. (2012). Business and Climate Change Adaptation: Toward Resilient Companies and Communities (p. $\quad$ 54). Retrieved from http://www.unglobalcompact.org/docs/issues_doc/Environment/climate/Business_and_Climate_Change_A daptation.pdf

Winn, M., Kirchgeorg, M., Griffiths, A., Linnenluecke, M. K., \& Günther, E. (2011). Impacts from climate change on organizations: A conceptual foundation. Business Strategy and the Environment, 20(3), 157-173. https://doi.org/10.1002/bse.679

Wittneben, B. B. F., \& Kiyar, D. (2009). Climate change basics for managers. Management Decision, 47(7), 1122-1132. https://doi.org/10.1108/00251740910978331

Yin, R. K. (2009). Case study research: Design and methods (4th ed.). Thousand Oaks, CA: Sage Publications.

\section{Copyrights}

Copyright for this article is retained by the author, with first publication rights granted to the journal.

This is an open-access article distributed under the terms and conditions of the Creative Commons Attribution license (http://creativecommons.org/licenses/by/4.0/). 